\title{
PROBLEM-BASED ENGLISH SPEAKING MATERIAL TO ENHANCE STUDENTS' CRITICAL THINKING SKILLS
}

\author{
Nur Rahmawati dan Ashadi \\ Graduate Program State University of Yogyakarta \\ email: nurrahma0910@gmail.com
}

\begin{abstract}
This study was aimed at examining the development of problem-based English speaking materials and the elements in the problem-based English speaking materials which can enhance grade X students' critical thinking skills. Employing a Research and Development design using Jolly and Bolitho's model (1998), the study collected data through observations, tests, interviews, and questionnaires to reach a comprehensive needs analysis. A total of 90 grade X students participated in the study. The product of this study was a set of supplementary materials for teaching speaking. Six units were developed; each of which consisting of six parts reflecting the problem-based stages. Based on the expert judgment, the mean score for all chapters was 3.69, equivalent to the range score of $3.25 \leq x \leq 4$ (very good). Chapter I and II were tried out to the students. The response showed that the mean score of each chapter was 3.2, equivalent to the range score of $2.5 \leq \mathrm{x} \leq 3.24$ (good). To conclude, the materials are appropriate to be used by $10^{\text {th }}$ graders because it meets their needs and it is designed based on the current curriculum.
\end{abstract}

Keywords: problem-based learning, speaking, critical thinking

\section{MATERI BERBICARA BAHASA INGGRIS BERBASIS MASALAH UNTUK MENINGKATKAN KEMAMPUAN BERPIKIR KRITIS}

\begin{abstract}
Abstrak
Penelitian ini bertujuan untuk mengetahui pengembangan materi berbicara bahasa Inggris berbasiskan masalah dan elemen-elemen dalam materi berbicara bahasa Inggris berbasiskan masalah yang dapat meningkatkan kemampuan berpikir kritis siswa kelas $\mathrm{X}$. Dengan melakukan penelitian dan pengembangan dengan mengadaptasi model Jolly dan Bolitho (1998), data dalam penelitian ini dikumpulkan melalui observasi, tes, wawancara, dan angket untuk mendapatkan hasil analisis kebutuhan yang komprehensif. Siswa kelas X sejumlah 90 orangberpartisipasi dalam penelitian ini. Hasil dari penelitian ini adalah satu set materi pendukung untuk mengajar berbicara. Enam unit materi sudah dikembangkan. Setiap unit berisi beberapa bagian yang mencerminkan langkah dalam pembelajaran berbasis masalah. Berdasarkan penilaian ahli, nilai rata-rata dari semua unit adalah 3,69 yang ekuivalen dengan rentang 3,25 $\leq x \leq 4$ dengan kriteria "sangat baik". Unit I dan II diujicobakan. Respons siswa menunjukkan nilai rata-rata masing-masing unit sebesar 3,2 yang ekuivalen dengan rentang 2,5 $\leq \mathrm{x} \leq 3,24$ dengan kriteria "baik". Kesimpulannya, materi yang sudah dikembangkan layak untuk digunakan karena sesuai dengan kebutuhan siswa dan kurikulum yang digunakan.
\end{abstract}

Kata kunci: pembelajaran berbasis masalah, berbicara, berpikir kritis 


\section{INTRODUCTION}

The need of learning, especially speaking in international communication, is gaining popularity including formal schooling setting as English becomes an international language. In Indonesia, people learn speaking to be able to communicate effectively. This is in line with the aim of the English lesson for the Senior High School students (Ministry of Education and Culture [MoEC], 2014). Therefore, English teachers need to facilitate their students with real-life activities which can encourage them to speak and communicate. They have to be trained to express and share their ideas in English to face any issue particularly in regard to this $21^{\text {st }}$ century challenges requiring the students to be engaged effectively with the issue in economic, civic, and global and to solve the problem on them in the future (Saavedra \& Opfer, 2012).

However, the speaking skill itself is not sufficient without the presence of $21^{\text {st }}$ century competencies as Jerald (2009, p. 31 ) argues that the knowledge and skills become the building block of someone's development to face the $21^{\text {st }}$ century challenges. There are four competencies called Four Cs namely critical thinking, communication, collaboration, creativity and innovation fitting in $21^{\text {st }}$ century skills. When the students think critically, they need these skills as a basis. Those two are required not only for the students' present life but also the future. Partnership for $21^{\text {st }}$ century learning or P21 (2011) characterizes critical thinking as the ability to reason effectively, use system thinking, make judgments and decisions, and solve problem. If teachers embedded this skill in curriculum, they will produce educated citizens and prepare them to face their job and life in the future (Stobaugh, 2013, p. 4). Wagiran (2007) also states that the characteristic of future jobs include having higher-order thinking skill, problemsolving, and working collaboratively. Therefore, students need to be prepared to focus on the future. It means soft skills also need to be integrated in the classroom. Soft skills as defined by Riyanti, Sandroto, and Warmiyati (2016, p.123) are the competencies in having a relation with people (inter-personal) and the competency on managing themselves (intra-personal). These skills include communication skill, creative thinking process, time management, relationship building or leadership. Bhanot (2009) argues that without soft skills, people have little chances of achieving success even with the best academic qualification. Therefore, senior high school students should also learn soft skills in order to be able to use their knowledge to communicate, work together, create acceptable language production, and think critically.

That argument is also in line with the objective of the Indonesian government's 2013 curriculum. Indonesian students are required to acquire such kinds of characters. One of the education's aims is to build the foundation or basis for the learners' development to be creative, innovative, and critical human (Government Regulation, 2010). It means that through education, students can be more responsive and critical toward any issue around the society.

However, based on the researchers' preliminary observation in some high schools in Yogyakarta, there have been insufficient materials and activities that guide the students to enhance their thinking skill, especially through speaking. The activities provided on the textbook used are mostly drilling or repeating the expression. Thus, these only facilitate the students' low-order thinking skills. They have not been guided to build high-order thinking 
skills. In addition, when they ask a question, they tend to base on provided information rather than criticizing a particular idea or asking beyond the text/context. In other words, the quality of the question is also lack of creativity and innovation. Besides, the use of role-playing, the most favorite way to teach speaking, is not meaningful. The teaching and learning in EFL classroom involved making dialogue and role-playing the dialogue they have designed. It does not seem that the students can use the language freely. This claim is supported by Dewi, Kultsum, and Armadi (2017) arguing that the English teacher usually asked the students to perform the text they have memorized. The students cannot speak freely based on their willingness because the teacher structured their speaking (repeating). Those activities provided by the teacher limit students' critical and creative thinking in using the language. The teaching and learning process only focuses on the cognitive level, such as memorizing, remembering, and may include practicing but sometimes it is not meaningful. The teachers could not provide the context where the students can use the language appropriately. Problem-solving activities are not integrated into the materials. Hence, the students are not sufficiently guided to develop their thinking skill higher.

In fact, the habit of thinking critically benefits people in their daily life. Lau (2011, p. 3) states that people will become better at obtaining the truth by rejecting bad idea. Being critical does not mean criticizing people all the time. When thinking other people wrong, critical thinking is used to identify the mistake by giving a hint or suggestion. Although people do not listen to reason, critical thinking can be used to think the best way to achieve the objectives. People also can decide which one is good or bad so they have the effort to improve it to be better. As being able to think critically brings some benefit, language teachers may integrate activities encouraging them to do so. Kurfiss (1988) argues that formal education process can affect someone's thinking style. He thinks that thinking style can be developed over a period of time. Therefore, providing activities that encourage students' critical thinking in formal education is urgent to be conducted.

In addition, Chodidjah (2013) argues that students should be equipped with English lessons that they can apply in their life after school to meet the requirements of the ASEAN Economic Community. Therefore, the materials should help the teachers to build students' critical thinking, collaboration, creativity, and communication to prepare them for globalization.

Problem-based activity is one of the methods that could facilitate the students to think critically and to participate actively in the class. Learning is related to thinking as in learning people need to think (Eggen \& Kauchak, 2012, p. 61). Thus, the more critical the students are, the more they study. Arendss and Kilcher (2010, p. 326) justify that problem-based activity is one of the way to incorporate problem-based learning (PBL) in the classroom. PBL is defined as a student-centered approach organizing curriculum and instruction around illstructured and real-world situations. The chosen problems need to have relation to their lives or at least be close to reallife as possible. Torp and Sage (2002, p. $15)$ embodies PBL as a process around curriculum involving the students as the participants in a given problem which facilitates student to learn in relevant ways. The process also forms a learning situation in which teachers becomes the guide in students' thinking and inquiry to facilitate deeper levels of understanding (Larsson, 
2001, p. 3). Therefore, students become more autonomous learners (MathewsAydinli, 2007, p. 5; Delisle, 1997, p. 3). Rahayu and Laksono (2015) argues that through PBL, the students can develop their skills, attitude, and scientific values in solving problem.

Mathews-Aydinli (2007, p. 5) and Larsson (2001, p. 3) believe that PBL may promote meaningful interaction as the students are focusing on real-world issues and problem. Regarding this, the students may improve their speaking as learners are willing to speak more in the class when they have a reason for communicating their ideas to solve a problem or give other classmates some information they need (Spratt, 2005, p. 37). By doing problem-solving activities, there will be a requirement not only for communication and interaction but also negotiation of meaning (Richards, 2006, p. 23). As a result, the students are pushed to speak. Thus, PBL becomes one way to facilitate the students to speak as speaking is considered as the most difficult skill to master (Bygate, 2001, p. 6). He argues that speaking happens very fast and the success of it depends on automation, the ability to consciously have the capacity to conceptualize, formulate, and articulate idea. People are also said to be successful in a speaking task if they can bring out conversation as they tend to do meaning negotiation (Nunan, 1991, p. 39).

In designing problem-based learning, the first consideration was the problem. Ikhwanuddin, Jaedun, and Purwantoro (2010) define problem as the difference between the present condition and the ideal situation. When people can identify the difference between what they have and what they want, it means they have set the problem and the goal that should be achieved. Weiss (2003, p. 26) highlights that a problem in problem-based learning should stimulate activity and high order thinking skills among students. A problem should be appropriate to students and must be based on the analysis of students' current knowledge. It should also be challenging if it is used as stimulus for critical thinking. The form of problem should be ill-structured, authentic, and messy like the real problem faced in everyday life or their future life. Moreover, the problem presented should engage students' collaboration to work in group. They discuss the problem, synthesis the idea, or negotiate meaning to propose a solution. It allows the students to draw solution from different fields and through this, they will be more motivated to do self-directed learning and encourage lifelong problem solving. This also represents the Four Cs described previously.

Problems may vary in term of the structuredness, complexity, dynamicity, and domain specificity or abstractness. Jonassen (2004, p. 8) proposes a typology of problems in which problems may vary. The typology is divided into 11 (eleven) types. The brief explanation for each problem is presented on Table 1.

Students can discuss the problem raised and decide the best solution by considering some factors or looking at different points of view. In selecting the solution, students do some discussions to express their idea and listen to others' ideas. They will improve their thinking skill by criticizing arguments presented by one of their friends. Students, therefore, should later become more tolerant of any opinion they receive.

Thus, this research aims at developing problem-based English learning materials for speaking to enhance students' critical thinking. This research also aims at finding out the elements in the problem-based English speaking materials which can 
Table 1

\begin{tabular}{lll}
\multicolumn{3}{l}{ A Typology of Problem } \\
\hline No & \multicolumn{1}{c}{ Problem Type } & \multicolumn{1}{c}{ Description } \\
\hline 1. & Logical problem & manipulate parts \\
2. & Algorithm & recall and apply procedures \\
3. & Story problem & identify and apply procedures \\
4. & Rule-using problem & use rules and procedures \\
5. & Decision making & consider choices and options \\
6. & Trouble-shooting & experiment through trial and error \\
7. & Diagnosis-solution & generate and test hypotheses \\
8. & Strategic performance & apply tactics within real time \\
9. & Case analysis & analyze, evaluate, and critique \\
10. & Designs & examine, correct, redesign/ redevelop \\
11. & Dilemmas & consider all factors and take a stand \\
\hline
\end{tabular}

enhance students' critical thinking skills appropriately.

\section{METHOD}

This study employs a Research and Development approach aiming at designing new products and procedures which should be field-tested, evaluated, and refined until they meet specified criteria of effectiveness, quality, or similar standard (Gall, Gall, \& Borg, 2003, p. 569). The setting of this study took place in a public high school near Yogyakarta, Indonesia. The current research began in March 2017 until September 2017 and involved 90 grade $X$ students as the sample of need analysis. These subjects were selected randomly for the try-out step involving two classes.

For this development, a model from Jolly and Bolitho (Tomlinson, 1998, p. 113) was adapted. The reason was because its steps were easy to follow and dynamic. There were some pathways that can be used as the option. The adaptation of the steps can be seen on the Figure 1 .

To collect the research data, several techniques were employed. First, the researcher distributed questionnaires to
90 students of grade $\mathrm{X}$. The study then proceeded with interviewing the English teacher, conducting brief test on critical thinking, observing students' speaking skills, and analysing documents and textbooks currently used. Those techniques aimed at finding students' target needs and learning needs. In order to gain feedback data of the product from the expert and try-out, four-scale model questionnaires were used. The criteria of the materials can be decided based on Table 2 .

Table 2

\begin{tabular}{|c|c|c|}
\hline \multicolumn{3}{|c|}{ Feasibility Criteria of Materials } \\
\hline No & Score & Criteria \\
\hline 1. & $1 \leq x \leq 1.74$ & Poor \\
\hline 2. & $1.75 \leq x \leq 2.49$ & Fair \\
\hline 3. & $2.5 \leq x \leq 3.24$ & Good \\
\hline 4. & $3.25 \leq x \leq 4$ & Very Good \\
\hline
\end{tabular}

The data from the interview, observation, documents, and textbook were analysed thematically based on the students' responses on desired input, instructional procedure, classroom setting, learners' roles, teacher's roles, lacks, wants, and necessities 
Figure 1. Jolly and Bolitho Model Adaptation

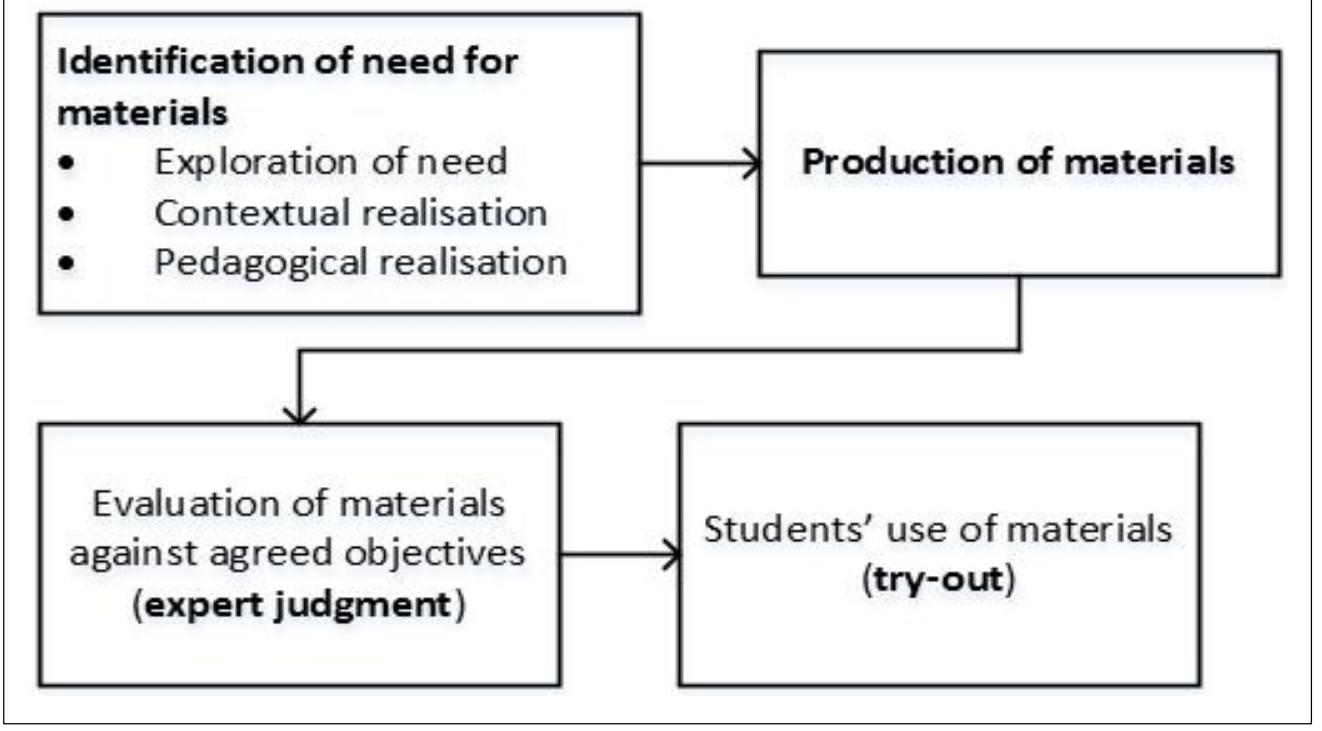

(Hutchison and Waters, 1987). To gain the validity and reliability, all the instruments used were validated by the experts in the field. The test of critical thinking was taken from the Delphi consensus patented (Facione, 1990). The materials were also validated by the expert in the field. They were tried out in a big classroom to see the students' response.

\section{FINDINGS AND DISCUSSION}

The information obtained as the basis for the development was related to students' target needs and learning needs. The target needs covered necessities, lacks, and wants from the students. The results are presented on Table 3. Meanwhile, the learning needs encompassed input, procedure, setting, learners' role, and teacher's role. The results are presented on Table 4.

All of the needs were considered, but the action was also adjusted as language teaching nowadays should be learnercentred (Richards, 2006, p. 5). The students should dominate the classroom activities. Since it becomes the requirement, the role of teacher preferred by most students is shifted into facilitator.

The data obtained were transformed into a course grid which includes the goals, the materials, the input, learning resources, and the sequences of activities. In deciding the speaking activity included, steps on developing speaking course followed what Richards (2015) suggested. He argues that the first step to do was determining the goals. The consideration was based on the Core Competence and Basic Competence as stated in the 2013 Curriculum from the Indonesian government. After that, selection of genre is needed to be made. For this research agrees with Richard (2015) who argues that small talk, conversation, transactions, discussion, and presentation belong into the genres for the materials. The last step to be done was choosing classroom activities including dialogue work, information gap, survey, role-play, storytelling, and picture descriptions. The selection was based on the characteristics of the materials and the students' need. The aim of those activities was to develop their strategies in speaking. 
Table 3

Target Needs of Grade X Students in Speaking Class

\begin{tabular}{cl}
\hline \multicolumn{1}{c}{ Aspect } & \multicolumn{1}{c}{ Point to Consider in Materials Development } \\
\hline a. Necessity & 1) Asking and giving information related to condition/ acts/ activities/ \\
events in the past. & 2) Asking and giving information related to historical events. \\
3) Retelling recount text (experience) related to historical events. \\
4) Asking and giving information related to legends. \\
5) Retelling legends. \\
6) Interpreting song lyrics related to teenager's life \\
Materials: \\
1) Asking and giving information related to condition/ acts/ activities/ \\
events in the past. \\
2) Asking and giving information related to historical events. \\
Critical thinking skills: \\
1) clarifying meaning \\
2) analyzing arguments \\
3) assessing claims and argument \\
4) justifying procedures \\
5) doing self-examination and self-correction \\
Type of problem preferred to solve: \\
1) Story problem \\
2) Design \\
3) Decision-making
\end{tabular}

Table 4

Target Needs of Grade X Students in Speaking Class

\begin{tabular}{ll}
\hline \multicolumn{1}{c}{ Aspect } & Point to consider in materials development \\
\hline a. Procedure & $\begin{array}{l}\text { Kind of activities: (1) Role-play, (2) information-gap, (3) discussion, } \\
\text { and (4) problem-solving }\end{array}$ \\
& $\begin{array}{l}\text { Type of input: (1) Video, (2) Audio, and (3) Text } \\
\text { b. Input }\end{array}$ \\
& Mength of input : 3-5 minutes or around100-300 words \\
& Grouping: (1) small group work, (2) pairs, (3) individual \\
c. Setting & (1) Lecturer, (2) Motivator, (3) Evaluator, (4) Corrector/giving feedback \\
d. Teacher's role & 1) Listening and repeating utterance \\
b. Learner's role & 2) Memorizing vocabulary \\
& 3) Participating actively
\end{tabular}

Besides, micro and macro skills of speaking proposed by Brown (2004) were also taken into account. The realization of macro skills was conducted by providing activities which helped students to accomplish communicative function, 
convey body language, and develop speaking strategies through discussion, presentation, and communicative activities (information-gap, survey). In order to help students produce differences among phonemes, produce fluent speech, use cohesive devices, activities like repeating vocabularies, presentation, and discussion were implemented as a form of micro skills realization. It is also in line with what Goh (2007) suggests that students need to master various skills in speaking competence. The development of the speaking materials considered the activities which can produce accurate sounds of target language at phonemic and prosodic levels, use spoken words to perform communicative functions, manage face-toface interactions, and establish coherence and cohesion in extended discourse. The previously mentioned activities fitted well with what Goh (2007) recommended to master speaking competence. In addition, Brown (2004) advised that the speaking skill was not supposed to be taught in isolation as a discrete skill. It has to be integrated with other skills like listening, reading, and writing.

The students would be motivated to speak if there is a reason for communicating (Spratt, 2005). Therefore, the existence of problem here became the reason why the students had to speak in order to solve the problem. In this development, the way of incorporating problem-based learning in the classroom was through problem based units. The sequences of activities represented the steps on PBL proposed by Arrend and Kilcher (2010). They were presenting the problem, planning investigation, conducting investigation, demonstrating learning, and reflecting and debriefing. Six units or chapters were developed to meet the students' needs and the employed curriculum. As Torp and
Sage (2002) proposed, this development was selected based on the curriculum by considering learners' needs and target needs.

As problem became the basis for the learning, its selection also needs to be considered carefully. The problem presented to the students was real-world problem and authentic, or at least relevant to students' life or future life (Larsson, 2001; Savin-Baden \& Major, 2004; Weiss, 2003). With the complexities of designing pure language problem in EFL context, the problem was designed at least to resemble the real-world problem. The designed problem was around the materials learned and it requires the students to speak in order to solve it. The first material talks about past events and it asks students to design an itinerary for a holiday as the problem presented. The students were asked to find as much as information to decide tourism destination and arrange a tour based on the situation provided. The problem for the second material is on invention. The students are asked to decide and make an invention from waste products around the environment. They have to discuss the possible and useful product and present it in a talk show. The problem is also linked to the future jobs like designing a self-video for job application in this case a museum guide. This problem is presented in Unit 3 of the materials. The students need to be able to retell historical events through a video. It is used as the way to fulfill requirement for the job.

An example of job vacancy on Figure 2 required the students to design a selfvideo retelling a historical event as job requirements. They have to analyze the problem's context and situation then discuss what they know, what they need to know, and what the action plan is. 
Figure 2. Example of Authentic Problem

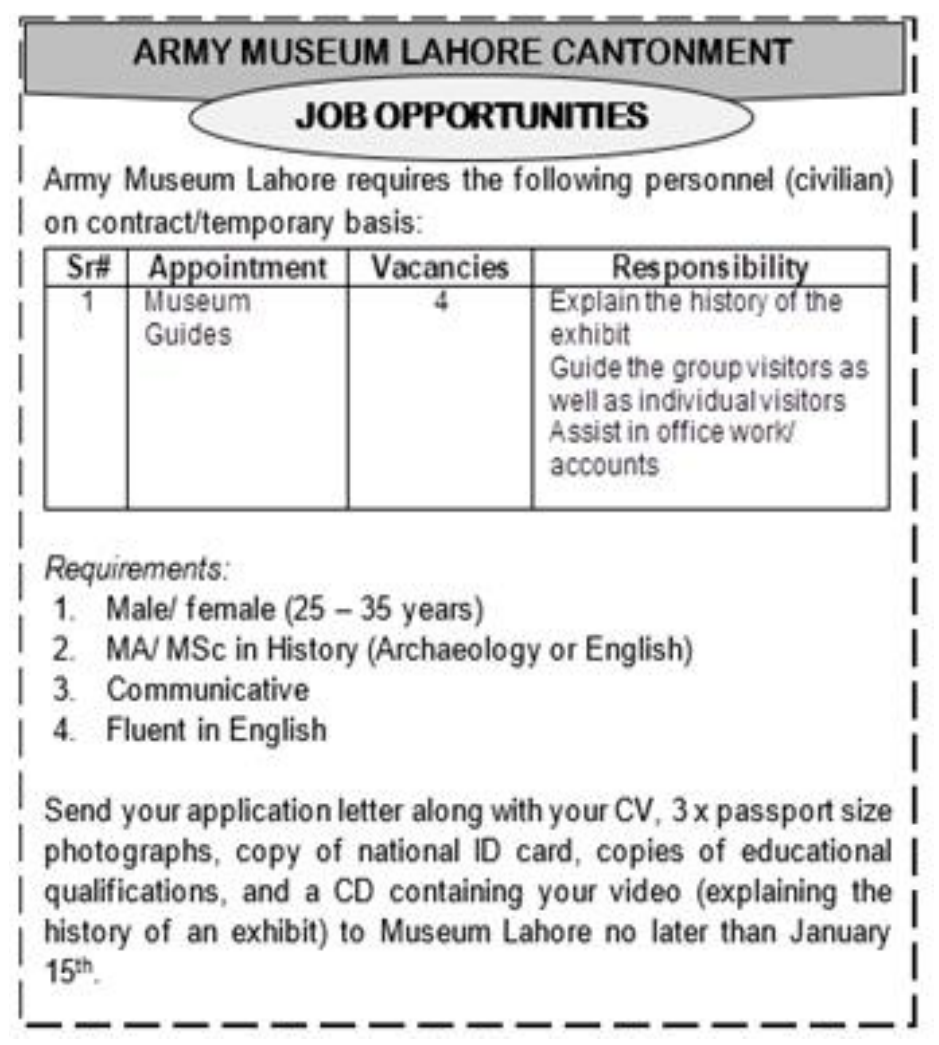

Note: Adapted from: jobnama.pk and adspk.pk

Materials for interpreting song were altered into a problem on deciding the most suitable song based on situations provided. The students need to listen to some songs then decide the appropriate song represented the situations by considering the idioms and expressions used. The last materials on recount text offer a problem on designing presentation for culture camp and planning a creative storytelling. The students have to discuss and choose the best strategies to win the competition. Some problems were taken and adapted from the real life problems, adjusted to the need of materials. The implementation was combined with other subjects like Economics and History in line with the idea of Larsson (2001) that problem-based learning may be done through combining language teaching with other subjects. However, teachers should be careful in choosing the problem and the subjects to combine. As the first draft depicted realworld problem and integrated History to the subject, the problem "finding facts and solution on Supersemar" was too abstract for the students. Therefore, the expert suggested to change the problem into more concrete real-world problem like designing a self-video for job application.

After the materials were ready, the next step was evaluating them. To examine the feasibility of materials, they were evaluated by the expert in the field of English 
materials development who happened to be a lecturer in a teachers' college. The evaluation covered five aspects to be observed. They were the feasibility of content, presentation, language, layout, and media. The questionnaire to evaluate the materials was adapted from BSNP and Graves (2000). Four scales model was used with score 4 representing "strongly agree", and score 1 representing "strongly disagree". The result is summarized in Table 5.

The data in Table 5 shows that the mean score range is from 3.68 to 3.7 . The distribution score of each aspect in each chapter was balance. The materials were feasible with the percentage score of $92.25 \%$ which qualitatively means 'very appropriate' to be tried out to find the students response on the use of materials in the classroom based on the expert's judgment. However, some revision had been made based on that evaluation. The main revision was related to the instruction in each activities which was considered too long and less effective by the expert, several instructions were simplified in brief and simple sentences were used as they are more suitable with the students' level of proficiency. Another revision was done by providing more guidance such as mind map or guidance table in What is the problem part and Investigation part. It implies that in problem-based learning, particularly in EFL context, there is a need for a guidance for identifying problem and conducting investigation. This idea was actually in line with Arrend and Kilcher (2010) idea to provide criteria, templates, or checklists to guide students planning and inquiry. In addition, revision for chapter III was on the problem presented to the students. The problem was too abstract for them. Initially, it was talking about students' ideas toward the Supersemar issue. Therefore, the problem was modified into designing a video for job application. This become real -world problem but it was not too abstract for the students. It implies that selecting problem is very crucial in designing problem-based learning. The materials developer should consider problem structuredness, complexity, dynamicity, and domain specificity or abstractness (Jonassen, 2004, p. 3).

After the revision stage, the materials was then tried out to see the success in the implementation process. Questionnaires were distributed to see the students' response toward the use of materials. The response consisted of five aspects to be observed namely the feasibility of the content,

Table 5

Score Comparison of Each Chapter (Expert Judgment)

\begin{tabular}{lcccccc}
\hline \multicolumn{1}{c}{ ASPECT } & $\begin{array}{c}\text { Chapter } \\
\text { I }\end{array}$ & $\begin{array}{c}\text { Chapter } \\
\text { II }\end{array}$ & $\begin{array}{c}\text { Chapter } \\
\text { III }\end{array}$ & $\begin{array}{c}\text { Chapter } \\
\text { IV }\end{array}$ & $\begin{array}{c}\text { Chapter } \\
\text { V }\end{array}$ & $\begin{array}{c}\text { Chapter } \\
\text { VI }\end{array}$ \\
\hline Content feasibility & 3.8 & 3.8 & 3.7 & 3.9 & 3.85 & 3.85 \\
Presentation feasibility & 3.9 & 3.9 & 3.7 & 3.9 & 3.9 & 3.9 \\
Language feasibility & 3.2 & 3.4 & 3.4 & 3.2 & 3.2 & 3.2 \\
Layout feasibility & 3.75 & 3.9 & 3.9 & 3.9 & 3.9 & 3.9 \\
Media feasibility & 3.7 & 3.4 & 3.6 & 3.6 & 3.6 & 3.6 \\
\hline Mean Score & 3.7 & 3.68 & 3.7 & 3.7 & 3.7 & 3.7 \\
\hline
\end{tabular}


presentation, layout, language, and media. The results of the students' responses are summarized in Table 6.

The table demonstrates that the mean score for both chapters was the same (3.2) which was equivalent to the range score $2.5 \leq \mathrm{x} \leq 3.24$. It means that the materials were 'good' based on the students' view on the five questioned aspects of the product. Based on the result, few minor revisions were made on the audio used to introduce the context. The students thought that the audio in chapter I was too fast, so they could not catch the words. Therefore, the speed of the audio was reduced a little bit. Moreover, there was an addition for teachers' guidance in the beginning of the book. This addition was proposed due to high intensity of students on asking for facilitation from the teachers. It was expected that the teacher's guide consisting the detail roles of the teacher in each step can make the teacher understand their role better in problembased learning.

The tried out of units took four to five meetings. It is in line with what Doghonadze and Gorgiladze (2008) propose that the implementation of problem based activity was time consuming. The students required more time to attain solution. They had to go through the steps of identifying the problem and conduct an investigation or study to propose the solution. However, if the teacher wants the students to acquire not only the knowledge but also the skills to acquire knowledge, this approach can be considered. While it can facilitate the students' speaking skill, their thinking skill will be getting higher. The activities of the developed materials were arranged and sequenced based on the steps on problembased learning by some authors (i.e. Arrend \& Kilcher, 2010; Torp \& Sage, 2002).

In designing problem-based classroom, Torp and Sage (2002) suggested to prepare the students who came from various background and interest before presenting problem. It is needed to provide warmup activities which can stimulate their motivation in the classroom. Teaching the content before presenting problem should be avoided. Therefore, Lead-in entailed some activities aiming at building and recalling students' background knowledge. They covered activities such as observing pictures, listening to a dialogue/audio, watching a video, and answering questions. It is expected that the students will have similar knowledge before meeting the problem.

After the students were ready, problems were presented. Arrend and Kilcher (2010) suggested that the problem should be illstructured (has more than one answer) and

Table 6

Try-out Score Comparison

\begin{tabular}{lcc}
\hline \multicolumn{1}{c}{ Aspects } & Chapter I & Chapter II \\
\hline Content feasibility & 3.2 & 3.2 \\
Presentation feasibility & 3.2 & 3.1 \\
Language feasibility & 3.1 & 3.26 \\
Layout feasibility & 3.3 & 3.24 \\
Media feasibility & 3.16 & 3.13 \\
Mean Score & 3.2 & 3.2 \\
Revision & Reducing the audio speed & Adding a guidance of \\
& & teachers' roles in every step \\
\hline
\end{tabular}


depict real-world situation. The introduction should be carefully planned to inspire and engage students' curiosity. This step belongs to What is the problem comprising activities presenting the problem. They were done through watching a video, listening to a dialogue/audio, or observing an advertisement/picture. There were some mind maps and tables to complete to help the students identify the problem, what they need, and what they plan. In this part, the students were required to be critical and careful in deciding the exact problem and the solution. They need to make judgment on the case they discussed. In this part, they were also 'forced' to discuss in English in order to solve the problem.

In Investigation part, the students complete a table or mind map to guide them on the investigation (Figure 3). They develop their curiosity in this part. They are also required to be critical to find out the facts and proofs to support their arguments by finding and reading many resources. Torp and Sage (2002) highlight that in this stage the students should be aware as they will argue on what task they should perform. They also have difficulties to locate information and select the relevant information needed. Therefore, teachers need to understand their role as the coach.

Students' confidence was facilitated through Presentation part. In this part, they present what they have learned and discuss or debate with each other. They might express and present their opinion. They practiced English by asking questions, and express their opinion toward the other group's presentation. In addition, they also become more critical as they listen and give feedback or questions to their friend's performance. They were also responsible to hold their arguments and give response to the questions. Arrend and Kilcher (2010) advise that the presentation can be done through an exhibit or classroom presentation. They may present in a small group or in front of the entire class. The teachers plays a role to give feedback in this stage.

Let's practice represents reflecting and debriefing steps. It involved some activities as reinforcement since the students had gotten the knowledge after solving the problem. Arrend and Kilcher (2010) claim that it is crucial to reflect on students' knowledge and skills they have acquired, the learning strategies they applied, or the

Figure 3. Example of Guidance to Do Investigation

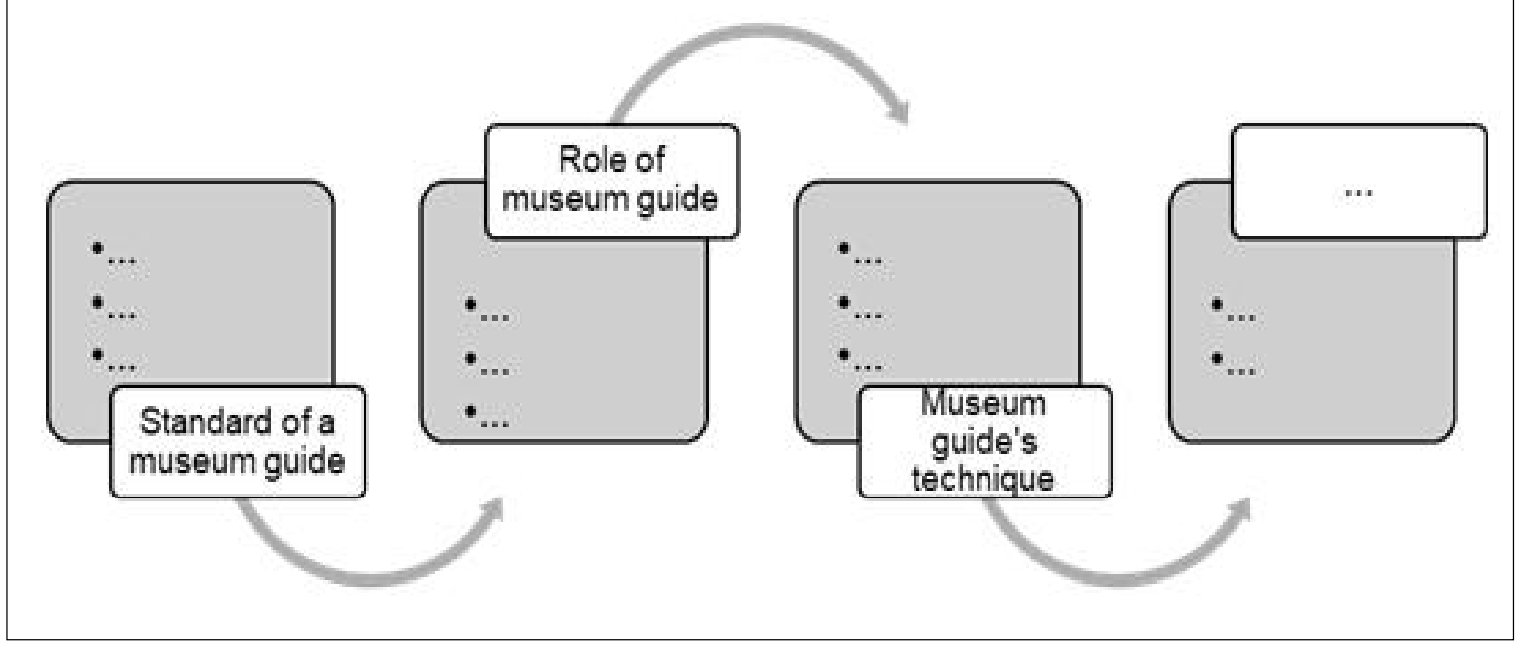


contribution they made to the group. Torp and Sage (2002) also suggested that it is needed to place the students in the field in which they will use the knowledge. Therefore, some activities can be presented to help them applied the knowledge. Various activities may be inserted like survey, information-gap, and storytelling. The example of reinforcement activity can be seen in Figure 4. This part aimed at developing students' strategies in speaking and also developing their fluency.

The last part was Self-assessment aiming at developing students' awareness of self-reflection. Richards (2015) recommends using learners' diary as a form of self-assessment to monitor their progress. The students completed the column to reflect on what they had learned, the difficulties they found, and the improvement they made during the lesson. It is expected that the students can identify preferred materials and ways of learning.
In each chapter, there were two additional parts namely Focus on language (Figure 5) and Culture in focus to increase students' awareness of language and culture. This is in line with Graves (2000) idea. He proposed six aspects to be considered in developing materials such as aspects on learners, learning, language, social context, activity, and materials. The materials developed should provide intercultural focus and have the ability to develop critical social awareness of the students.

Those elements help the students to improve their critical thinking. Since the first step, they have to be critical in identifying the problem and deciding the appropriate solution. They should also be critical in presentation sessions when they give feedback or comment to their friends' performance. They should be critical in responding and defending their arguments. Furthermore, the problem presented was mostly on designing, invention, and decision

Figure 4. Example of Reinforcement Activity

\section{Activity 9}

Select your most favourite legend in Indonesia. Retell it using your own word in a good order in front of the class. You may use series of pictures to guide you. Don't forget to use past tense and pay attention to the following guideline below.

Figure 5. Example of Language Focus

Language in focus

\section{Asking information}

What was your invention?

When did you invent it?

Where did you get the inspiration?

Why did you invent that?

What was your reason for inventing that?

How was the use of it?

\section{Giving Information}

It was

In 1900/ When I was

When I was having

Because I thought that .

Because, ....

First, ... Second, 
making. This became the way to improve the students' critical thinking. Krathwohl (2002) highlights that designing belongs to the highest cognitive process. People needed to put some parts together to form product. When people are provided with activities in this cognitive level, it means that they are guided to develop their critical thinking skill higher. Moreover, Heong (2011) argues that there are 13 higher-order thinking skills (HOTS) identified as the extended use of mind to meet new challenges. They include the ability to compare, classify, induce, deduce, analyze error, construct supporting, analyze perspective, abstract, make decision, investigate, solve problem, conduct experiment, and make an invention. It can be said that the problems presented in the materials had guided the students to develop their thinking skills higher as they are related to invention, decision making, problem solving, investigation, and comparison. Thus, based on the activities in each stage and the types of problem presented, this book can be used to build students higher-order thinking skills.

Actually, these parts in problem-based learning (PBL) were really similar to parts of other approaches like genre-based approach (GBA), scientific approach (SA), taskbased approach (TBA), and the like which require lead-in activities in the beginning, considering receptive skill, and the activity with production activities at the end. This means that actually all the approaches has no difference in term of division parts. The difference is only on the root, base, or focus. PBL is rooted on the problem, GBA focuses on the genre, SA is based on scientific actions, and TBA focuses on task sequences. Nevertheless, the functions of each step is similar. Perhaps, the most important aspect to consider in designing a problem based activity is the designed problem. As argued by Savin-Baden and
Major (2004) that teachers need to consider the students' prior knowledge, the context, and the way to present problem.

Moreover, Richards (2006, p. 41) claims that GBA could not promote more creativity and personal expression of the students as they only follow the model text. In addition, he also thinks that TBA focuses on process rather than on the outcome ( $\mathrm{p}$. 35 ). Therefore, it can be analyzed that PBL can attain creativity, process, and also outcome. It can be seen that through the stages of PBL, the students can develop their creativity and critical thinking. Also, they were on the process of deep learning as they find the materials by themselves through solving problem. In the end of the lesson, they have to practice or demonstrate a language production with the materials they learned. These explanations implied that PBL may become an alternative approach, particularly in English language teaching, to meet the demand of globalization as it can develop students' creativity, communication, collaboration, and critical thinking.

The sequences of problem-based learning represents the way the students find the materials by themselves with guidance from the teacher. They gain deeper understanding through having investigations on the problem they worked on. They take benefits from many resources including technology to do the investigations. Yet, teachers still become a facilitator in order to help the students and guide them to achieve the aim of the lesson. This approach can be used an alternative approach in teaching English, particularly to improve students speaking skill and critical thinking skill. The importance was placed on the problem presented to the students. The teacher may select and adjust the problem based on the aim of the lesson, the skills that the students should achieve, and the students' knowledge. It is expected that learning 
through problem-based learning produces not only educated students, but also critical students to prepare for the changes in $21^{\text {st }}$ century life where technology plays important roles in the education and society.

To conclude, according to the result of expert judgment and the students' use of materials, the product developed can be said as appropriate and feasible to be used and implemented in the classroom, particularly grade $\mathrm{X}$ students of semester II. The materials had met the students' needs and the 2013 curriculum. The elements of problem based learning like the type of activities and problem presented, perhaps can be used as the means to help students develop and improve their thinking skills higher.

However, due to the limited sampling, time, and field try-out, only two of the six units of materials developed were tried out. The field-testing was carried out once in a big classroom consisting around 30 students. The tryout should have been conducted to grade $\mathrm{X}$ students in semester II. However, due to long process of materials development, the trial managed to be done to the same subject but on grade XI.

\section{CONCLUSIONS}

The product of this study was a set of supplementary materials covering six units developed on the basis of needs analysis. The development of the materials started from identifying learners' need for materials, producing the materials, evaluating the materials through expert judgment, and field testing the materials through students' use of it. From these stages, the developed materials were considered as appropriate or feasible to be used as they met the students' needs and the current 2013 curriculum.

The materials can be used as supplementary materials for teaching English, particularly in improving speaking skills through problem-based learning. However, as it takes some time to implement the PBL, the teachers may consider focusing on the content or the process of achieving the targeted knowledge or skills. With the activities and problems that require the students to think critically, the problembased materials have a great potential to prepare students to face the future jobs which demand them to be critical, communicative, collaborative, and creative. The most crucial aspect to consider was the problem presented which should be ill-structured which has more than one answer and depict real-world problem. Teachers should, therefore, understand their roles in each stage and consider the length of each activity as problem-based learning takes some time to implement. This study has also created a space for further research to examine for example, the types of problems, the creation of realworld problems, and the detailed roles of the teachers in PBL particularly in foreign language learning setting.

\section{REFERENCES}

Arendss, R. I., \& Kilcher, A. (2010). Teaching for student learning: Becoming an accomplished teacher. New York: Routledge.

Bhanot, S. (2009). Importance of soft skills for an employee for the organization. SIES Journal of Management, 6(1),1822.

Brown, H. D. (2004). Language assessment: Principles and classroom practices. New York: Pearson Education.

Bygate, M. (2001). Speaking. In R. Carter \& D. Nunan (Eds.), The cambridge guide to teaching English to speakers of other language (pp. 14-20). Cambridge: Cambridge University Press. 
Chodidjah, I. (2013). ELT in the Indonesian school system. Retrieved from http:// bruneiusprogramme.org/wp-content/ uploads/2013-Forum-PublicationComplete.42-46.pdf.

Delisle, R. (1997). How to use problembased learning in the classroom. Virginia: ASCD.

Dewi, R. S., Kultsum, U., \& Armadi, A. (2017). Using communicative games in improving students' speaking skills. English Language Teaching, 10(1), 63-71.

Doghonadze, N., \& Gorgiladze, G. (2008). Problem solving in teaching foreign languages to students of pedagogical departments. Scientific Journal of International Black Sea University, 2(1), 101.

Eggen, P., \& Kauchak, D. (2012). Strategies and models for teachers: Teaching content and thinking skills ( $\left.6^{\text {th }} \mathrm{ed}\right)$. Boston: Pearson Education.

Facione, P. A. (1990). Critical thinking: A statement of expert consensus for purposes of educational assessment and instruction-The Delphi report. Millbrae, CA: California Academic Press.

Gall, M. D., Gall, J. P., \& Borg, W. R. (2003). Educational research: An introduction ( $7^{\text {th }}$ Edition). Boston: Allyn and Bacon.

Goh, C. C. M. (2007). Teaching speaking in the language classroom. Singapore: SEAMEO Regional Language Centre.

Government Regulation. (2010). 17 C.F.R. $\S 77$.

Graves, K. (2000). Designing language courses: A guide for teachers. Canada: Heinle \& Heinle.

Heong, Y. M., Othman, W. B., Yunos, J. B. M., Kiong, T. T., Hassan, R. B., \& Mohamad, M. M. B. (2011). The level of marzano higher order thinking skills among technical education students. International Journal of Social Science and Humanity, 1(2), 121-125.

Hutchinson, T \& Waters, A. (1987). English for specific purposes: A learningcentered approach. Cambridge: Cambridge University Press

Ikhwanuddin, Jaedun, A., \& Purwantoro, D. (2010). Problem-solving dalam pembelajaran Fisika untuk meningkatkan kemampuan mahasiswa berpikir analitis. Jurnal Kependidikan, 40 (2), 215-230. Retrieved from https://journal.uny.ac.id/index.php/jk/ article/view/500/360.

Jerald, C. D. (2009). Defining $21^{\text {st }}$ century education. Retrieved from http://www. centerforpubliceducation.org/LearnAbout/21st-Century/Defining-a-21stCentury-Education-Full-Report-PDF. pdf.

Jolly, D., \& Bolitho, R. (1998). A framework for materials writing. In B. Tomlinson (Ed.) Materials development in language teaching (pp. 90-115). Cambridge: Cambridge University Press.

Jonassen, D. H. (2004). Learning to solve problems: An instructional design guide. San Fransisco: Pfeiffer.

Kurfiss, J. G. (1988). Critical thinking: Theory, research, practice, and possibilities. ASHE-ERIC Higher Education Report No. 2, 1988. The George Washington University, Washington.

Krathwohl, D. (2002). A revision of Bloom taxonomy: An overview. Theory into Practice, 41(4), 212-218

Larsson, J. (2001). Problem-based learning: A possible approach to language education. Jagiellonian University, Kraków, Polandia.

Lau, J. Y. F. (2011). An introduction to critical thinking and creativity: Think 
more, think better. New Jersey: John Wiley \& Sons.

Mathews-Aydinli. (2007). Problem-based learning and adult English language learning. CAELA Brief, April 2007.

Ministry of Education and Culture, 59 C.F.R 1. (2014).

Nunan, D. (1991). Language teaching methodology: A textbook for teachers. Sydney: Prentice Hall.

Richards, J. C. (2006). Communicative language teaching today. New York: Cambridge University Press.

Richards, J. C. (2015). Key issues in language teaching. Cambridge: Cambridge University Press.

Rahayu, R., \& Laksono, E. W. (2015). Pengembangan perangkat pembelajaran IPA berbasis problem-based learning di SMP. Jurnal Kependidikan, 45(1), 29-43. Retrieved from http:// journal.uny.ac.id/index.php/jk/article/ download/7184/6194.

Riyanti, B. P. D., Sandroto, C. W., \& Warmiyati, M. P. (2016). Soft skill competencies, hard skill competencies, and intention to become entrepreneur of vocational graduates. International Research Journal of Business Studies, 9(2), 119-132.
Saavedra, A. R., \& Opfer, V. D. (2012). Learning $21^{\text {st }}$-century skills requires $21^{\text {st }}$-century teaching. Phi Delta Kappan, 94(2), 8-13.

Savin-Baden, M., \& Major, C. (2004). Foundation of problem-based learning. Maidenhead: Open University Press.

Spratt, M. et al. (2005). The TKT (teaching knowledge test) course. Cambridge: Cambridge University Press.

Stobaugh, R. (2013). Assessing critical thinking in Middle and High schools: Meeting the common core. New York: Routledge.

Torp, L \& Sage, S. (2002). Problems as possibilities: Problem-based learning for K-16 education. Virginia: ASCD.

Wagiran. (2007). Peningkatan keaktifan mahasiswa dan reduksi konsepsi melalui pendekatan problem-based learning. Jurnal Kependidikan, 37(1), 1-22. Retrieved from: http:// journal.uny.ac.id/index.php/jk/article/ view/4984/4289.

Weiss, R. E. (2003). Designing problems to promote higher-order thinking. New directions for teaching and learning, 2003(95), 25-31. 